\title{
Selection of Compatible Ground Motions with the Seismic Characteristics of Erbil City, the Capital of the Kurdistan Region of Iraq
}

\author{
Zina A. Abduljaleel ${ }^{1 *}$, Bahman O. Taha \\ Department of Civil Engineering, Erbil Technical Engineering College, Erbil Polytechnic University, Erbil, Kurdistan Region, Iraq
}

\author{
*Corresponding author: \\ Zina A. Abduljaleel, \\ Department of Civil \\ Engineering, Erbil Technical \\ Engineering College, Erbil \\ Polytechnic University, Erbil, \\ Kurdistan Region, Iraq. \\ E-mail: zina.abduljaleel@ \\ epu.edu.iq
}

Received: 18 September 2019

Accepted: 13 May 2020

Published: 30 June 2020

\section{DOI}

10.25156/pti.v10n1y2020.pp110-120

\begin{abstract}
A B S TR A C T
Erbil city characterized by the risk of earthquakes generated by Zagros-Taurus Belt. The central objective of this study is to obtain a compatible input ground motion within the seismicity of Erbil city since which is considered an essential component of seismic risk evaluation and vulnerability studies. The real records obtained from the online database Pacific Earthquake Engineering Research Next Generation Attenuation. Four sets of ground motion selection and modification methods proposed to obtain fifteen records, where each record scaled and matched with the defined target spectra and seismic characteristics in Erbil city. Based on the greatest number of repetition and different events, ten compatible ground motions with earthquake name and NGA record number are selected: Gazli Ussr (\#126), Imperial Vally 06 (\#183), El Mayor-Cucapah_Maxico (\#5827), Christchurch_New Zealand (\#8124), Imperial Valley (\#6), Darfield_NewZealand (\#6893), Duzce Turkey (\#1602), Northridge_01 (\#1082), Loma Prieta (\#761), and Spitak_Armenia (\#730). Seismosoft application utilized to obtain the graphs of acceleration, velocity, and displacement time histories for three components, in addition to determine the important parameters to characterize the amplitude, frequency content, and duration of the selected ground motion.
\end{abstract}

Keywords: Earthquake records; Erbil; Ground motion; Seismic characteristics; Time history

\section{INTRODUCTION}

Erbil city suffers from the forces driven by the counterclockwise movement of the Arabian plate toward the N-NE [Figure 1] and its displacement underneath the Eurasian plate at a rate of about $2-3 \mathrm{~cm} /$ year (Alsinawi, 2006). The activity of seismic associated with the collision subduction zone between the Arabian plate and the Iranian and Turkish plateaus is mainly dictated by the Bitlis-Zagros Fold and Thrust Belts (Abdulnaby et al., 2014a; Ghalib and Aleqabi, 2016).

More recently, the activity of the Zagros fault has been increased significantly. After the recent earthquakes, especially in Erbil city has raised many questions about the safety of structures. For this purpose, input ground motions are a key component of seismic risk studies, especially for the time history analyses. Thus the current study concentrated on the selection of the real ground motions which is appropriate to the seismic characteristics of Erbil city.

\section{LITERATURE REVIEW}

In literature, there are three sources of acceleration time histories, as shown in Figure 2:
1. Recorded accelerograms in real earthquakes scaled to match design code spectrum/uniform hazard spectral/ condition mean spectrum

2. Artificial records generated from white noise spectra to satisfy design code spectrum

3. Synthetic records obtained from seismological models.

Artificial and synthetic records are not approved in the time history analysis since the artificial accelerogram is often an excessive number of cycles of strong motion, and consequently, have an unrealistically high-energy content.

Besides, the parameters (e.g., earthquake scenario, the location of the site, and geological condition) to generate synthetic accelerograms are not often available, especially when using seismic design codes (Bommer and Acevedo, 2004).

Real strong ground motion accelerograms are natural observations which reflect all the factors that influence accelerograms (characteristics of the source, path, and site), in addition to real records, contain resources of information about the nature of the ground shaking and carry all the ground motion features (amplitude, frequency, energy content, duration, and phase properties). The real 


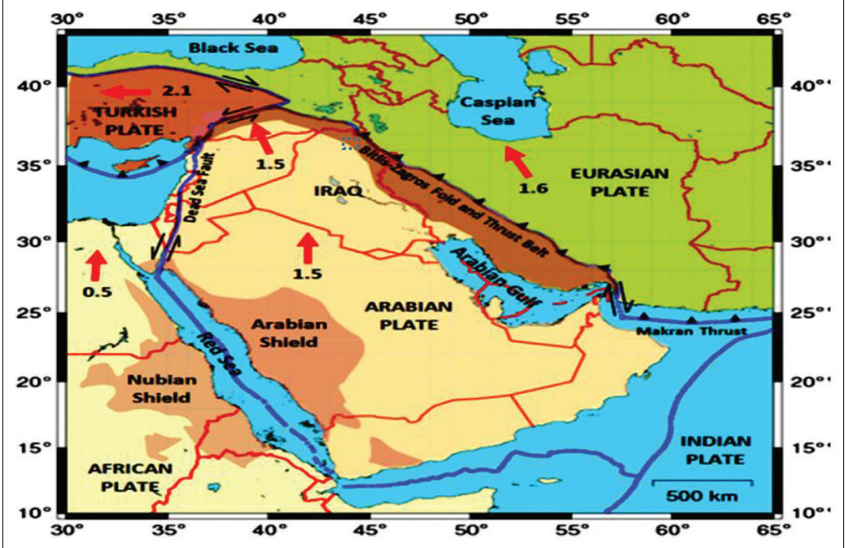

Figure 1: Tectonic map of Arabian and Eurasian plate (Abdulnaby et al., 2014a)

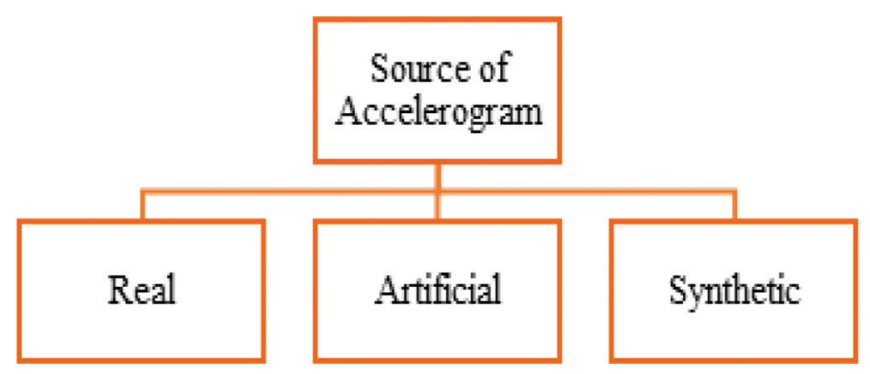

Figure 2: Source of strong motion records

accelerogram records available in online databases (e.g., Pacific Earthquake Engineering Research Next Generation Attenuation West2 [PEER NGA-West2]) flat-file database, which includes more than 21,000 for components ( two horizontal of $\mathrm{H} 1$ and $\mathrm{H} 2$, and the vertical component) from more than 500 shallow crustal earthquakes in the active global tectonic regimes (Ancheta et al., 2014).

In the online (PEER-NGA-West2) database, the important criteria should be considered in the selection input seismic related to geographical data of the region and the maximum response of the structure, in which crucial criteria includes the following parameters (Das et al., 2018):

1. The magnitude of the source

2. Types of source

3. The condition of the site

4. Site to source distance

5. Number of records per event

6. Strong motion instrument location.

In literature, there are many methods of ground motion selection and modification (GMSM) desirable for use in dynamic analysis. Regrettably, there is no agreement as to the accuracy and precision of these methods in predicting the structural response; thus, the choice of which method to use remains largely subjective. This has a significant impact on the engineering community since the non-linear response is critical to the selection and modification of input ground motions. GMSM Program was formed in PEER center to overcome these arguments (Goulet et al., 2008).

To overcome the problem of ground motion selection, Haselton et al. investigated many procedures. As a result, they proposed only fourteen from more than forty methods for choosing appropriate GMSM methods (Haselton et al., 2009). To investigate the dynamic behavior of RC structures, Haselton et al. reviewed the five groups of GMSM methods as follows:

1. Selection by magnitude (M) and distance (R) and scaling to $\mathrm{Sa}(\mathrm{T} 1)$

2. Selection and scaling using uniform hazard spectrum

3. Selection and scaling conditional mean spectrum

4. Selection and scaling Proxy from conditional mean spectral (CMS)

5. Selection and scaling considering inelastic spectral.

Based on the median response of maximum interstory drift ratio of the buildings, they asserted the level of accuracy obtained with the ground motion selection Group3, followed by Group 4, 5, 2, and Group 1 (Haselton et al., 2009).

Yaseen et al. examined the safety of the unreinforced masonry buildings in KR of Iraq, which was prepared four independent sets of fifteen ground motions, the real records obtained from PEER NGA database, considering the variability of GMSM, they proposed GMSM methods in the following sets (Yaseen et al., 2015, 2014):

1. Target response spectra (RS) proposed by the author, for each seismic hazard zones in KR of Iraq

2. Target RS defined by seismic design code EC8

3. Ground motion selection using the CMS proposed by Baker

4. Ground motion selection using an algorithm proposed by Jayaram et al.

Generally, there are two main methods for scaling and modifying a time series to match the design response spectrum (target spectra):

1. Time history scaling: This method involves modifying a time history's scale (and/or) time steps to try to closely match the target spectrum

2. Spectral matching: This method comprises a timedomain modification of an acceleration time history so as to compatible with a target spectrum. Based on the original method proposed by Lilhanad and Tseng (1987), which is also Abrahamson's (1992) use of computer programing code for spectral matching called RPS match, consequently updated by Hancock et al. (Hancock et al., 2006). 
Galin supported to use modified real records, which studied the results of the selection and scaling of ground motions on the response of linear/nonlinear time history analysis for multi-story RC buildings. It was affirmed that the scaled real records seem to be preferable in such an analysis and that a simulated accelerogram should be used in a case where real records are unavailable (Galin, 2012).

Concerning the number of ground motions, for intensitybased assessments, mean values are generally investigated for each response quality of interest, this is the evidence for the acceptance criteria of the current ASCE-7-10 standard (ASCE/SEI 7-10, 2010; Reyes and Kalkan, 2011) and is typically accomplished using a set of seven ground motion records. However, ATC-58 stipulated eleven ground motions (ATC, 2011).

\section{SEISMIC CHARACTERISTICS OF ERBIL CITY}

To obtain ground motion compatible with the seismic characteristics of Erbil city, the geology and seismology of the city briefly reviewed and summarized as follows:

1. Tectonically, Erbil city is classified by an outer platform of the low folded zone in the position of Western Zagros Fold-Thrust Belt (Fouad, 2015), which is essentially suffering from the risk of earthquakes generated by Zagros-Taurus Belt

2. Geologically, Erbil city is covered by quaternary sediments and lithologically by fluvial sediments (Fouad and Sissakian, 2015)

3. Dynamic soil properties are classified by site class $\mathrm{D}$, according to the code of practice and shear wave velocity, based on the database prepared by Mohammed and Abdulrassol (Mohammed and Abdulrassol, 2017)

4. Seismicity review indicated that the seismic source characterized by strike-slip (Normal) fault (Abdulnaby et al., 2014b), and majority events exhibit at the shallow crustal with expected moment magnitude between 6 and 7.5 (Hosseini et al., 2014a; Onur et al., 2016; Said and Farman, 2018a, 2018b; Al-Shijbi et al., 2018; ElHussain et al., 2018)

5. According to the previous hazard assessment studies, PGA identified by $0.4 \mathrm{~g}$ for 2475 years (Hosseini et al., 2014b; Yaseen et al., 2014; Onur et al., 2016; Said and Farman, 2018a, 2018b; Al-Shijbi et al., 2018).

\section{PROPOSED METHODOLOGY FOR SELECTING AN APPROPRIATE GROUND MOTION}

1. Choosing GMSM methods

2. Selection of ground motion data set
3. Selection of ten records, considering a significant number of repetitions (e.g., two times and more), and different events.

\section{Choosing GMSM Methods}

Considering the variability in the number of ground motions, a substantial number of available RS from the PEER NGA-West2 online database (https://ngawest2. berkeley.edu/) is scaled to match the target spectra defined by the following GMSM methods.

- Method I: Ground motion selection and scaling using target RS defined by Onur et al. (Onur et al., 2016) and their study of probabilistic seismic hazard analysis (PSHA), for 2475 years return period, represented in Figure 3, which is also considered a basis for the Draft of Iraqi Seismic Code (Draft/ Code-16, 2016)

- Method II: Ground motion selection and scaling using unified hazard spectrum (UHS) spectra defined by updated PSHA for Iraq/2018, for 2475 years return period (Said and Farman, 2018b). Figure 4 represents the target spectra defined in Method II

- Method III: Ground motion selection and scaling using ASCE code (ASCE/ASE07-10, 2013), and spectra defined by PSH maps for Arabian plate/2018, for 2475

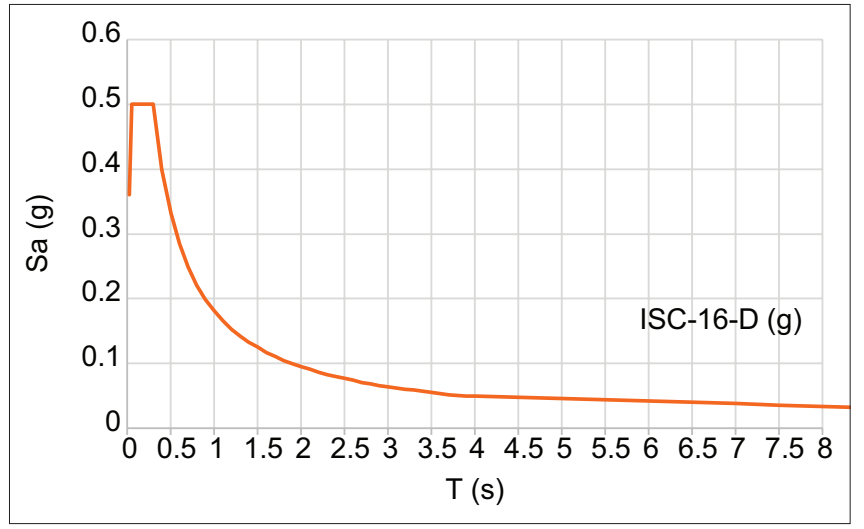

Figure 3: Target response spectra in Method I

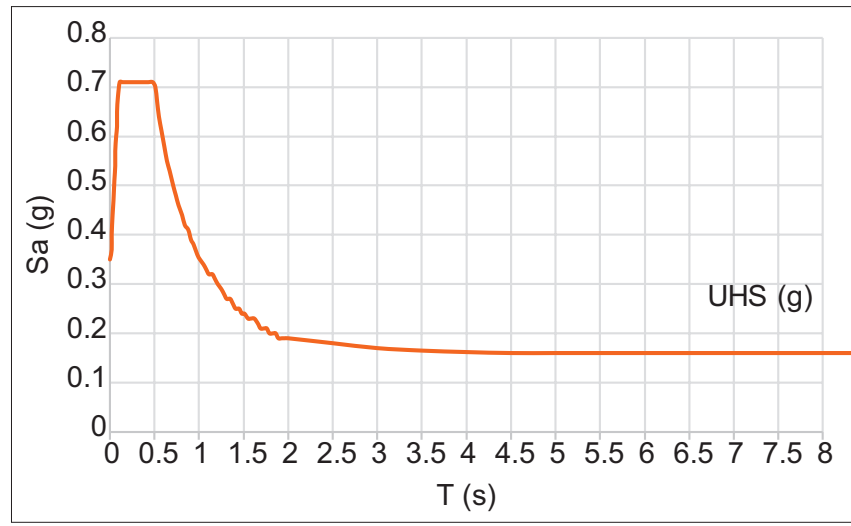

Figure 4: Target spectra in Method II 
years return period (Al-Shijbi et al., 2018). Figure 5 shows the target spectra defined in Method III

- Method IV: Ground motion selection and scaling using proposed condition mean spectrum (CMS) by means of PEER-NGA spectrum (PEER, 2018).

Baker explained that the CMS is an appropriate target response spectrum for selecting the ground motion, comparing to UHS target spectrum. CMS can be recognized in a term of "Conditional" conditional upon natural period and the specified RS at that period, and the term "mean" the remainder of the spectrum consists of the mean spectra value shown in Figure 6 (Baker, 2011).

Baker emphasized on the CMS approach ground motion selection for conducting performance-based engineering, the author discussed that the CMS has a great impact in the predicting structural response than other approaches. Consequently, various tools available to obtain the CMS, for example (U.S. geological survey national hazard maps products, software such as EZ-FRISK and online program PEER-NGA-West2); moreover, the CMS determined by considering the seismological inputs (e.g., magnitude M, distance R, and Epsilon $\varepsilon$ ), where Epsilon is a parameter

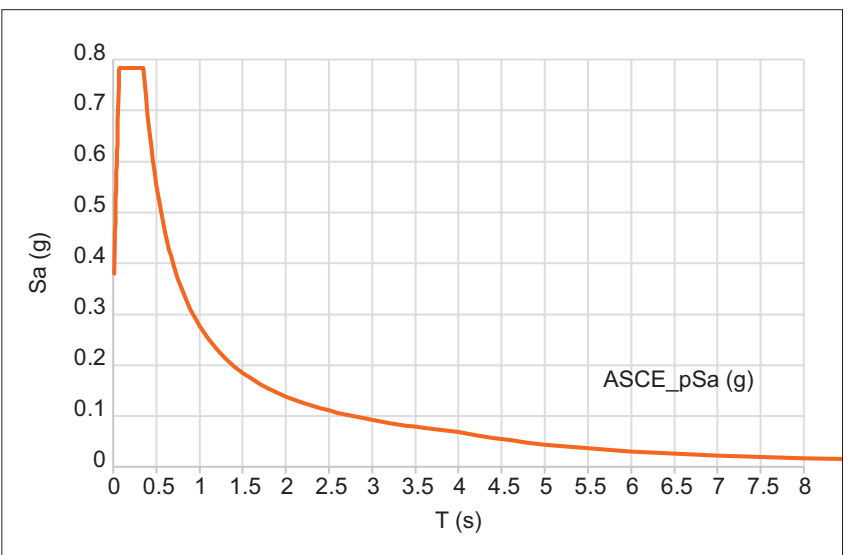

Figure 5: Target response spectrum in Method III

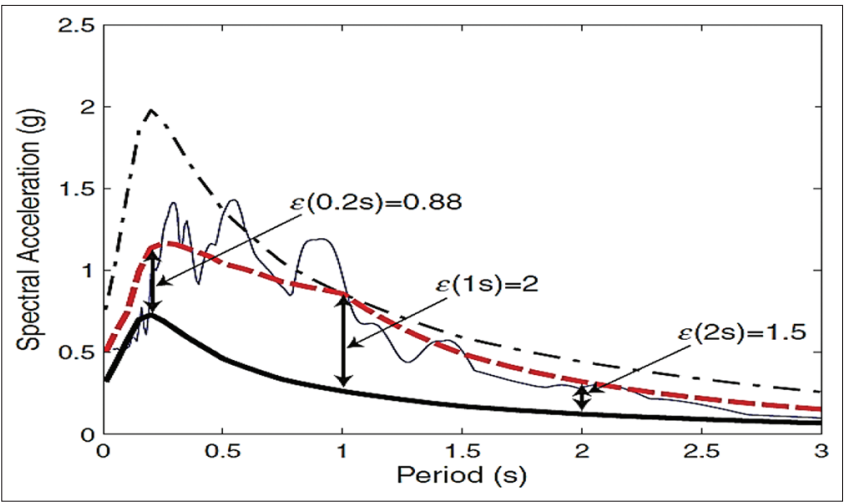

Figure 6: Actual time history fit the condition mean spectrum (Baker, 2011) related to the earthquake which was described as the number of standard deviations by which an observed value differs from the mean, predicted by the equation below (Baker, 2015):

$$
\varepsilon=\frac{\ln S_{a}(T)-\mu_{\ln S_{a}}(M, R, T)}{\sigma_{\operatorname{lnS}_{a}}(T)}
$$

Where

$\mu_{\operatorname{lnSa}}(\mathrm{M}, \mathrm{R}, \mathrm{T})$ and $\sigma \ln _{\mathrm{Sa}}(\mathrm{T})$ : Predicted mean and standard deviation, respectively, of $\ln \mathrm{S}_{\mathrm{a}}(\mathrm{T})$ at a given period.

$\ln \mathrm{S}_{\mathrm{a}}(\mathrm{T})$ : Natural logarithm of spectral acceleration value of interest.

For the purpose of CMS, UHS is calculated from the spreadsheet adopted by Sayhan in PEER research center (PEER, 2018). Four equal weight (0.25) of ground motion prediction equation model (GMPE) is used: Abrahamson et al., 2014 (ASK14), Boore et al., 2014 (BSSA14), Campbell and Bozorgnia, 2014 (CB14), and Chiou and Youngs, 2014 (CY14), for a standard deviation (Sta.dev.) is $1 \%$, and damping ratio $5 \%$. The result of the GMPE, median value, and median value with (Sta.dev.) is represented in Figure 7.

Consequently, CMS was constructed for epsilon which is 1 for an eighty-fourth percentile spectrum and using NGA models and coefficient model by Baker and Jayaram (2008) at a spectral period of $0.5 \mathrm{~s}$, as shown in Figure 8.

\section{Selection of Ground Motion Data Set}

The PEER NGA-West2 online database (https:// ngawest2.berkeley.edu/) is arranged to select four sets of fifteen records compatible with the seismic characteristics of Erbil city. Table 1 represents the four sets of fifteen records. Figure 9 shows the matched RS for the selected ground motions and their geometric mean to the target response spectrum.

\section{RESULTS AND DISCUSSION}

\section{Selected ten Ground Motion Data Set}

For the purpose of dynamic analysis, the unification and the minimum number of records recommended by ASCE standard, the most recurrent records (e.g., ten records) among the four sets of fifteen records are selected, this methodology leads to overcome the gap in the range of required seismic properties, including the earthquake magnitude, epicentral distance, and intensity measurement. The events were selected based on six records are with two repetitions, two records are with three repetitions, and two 


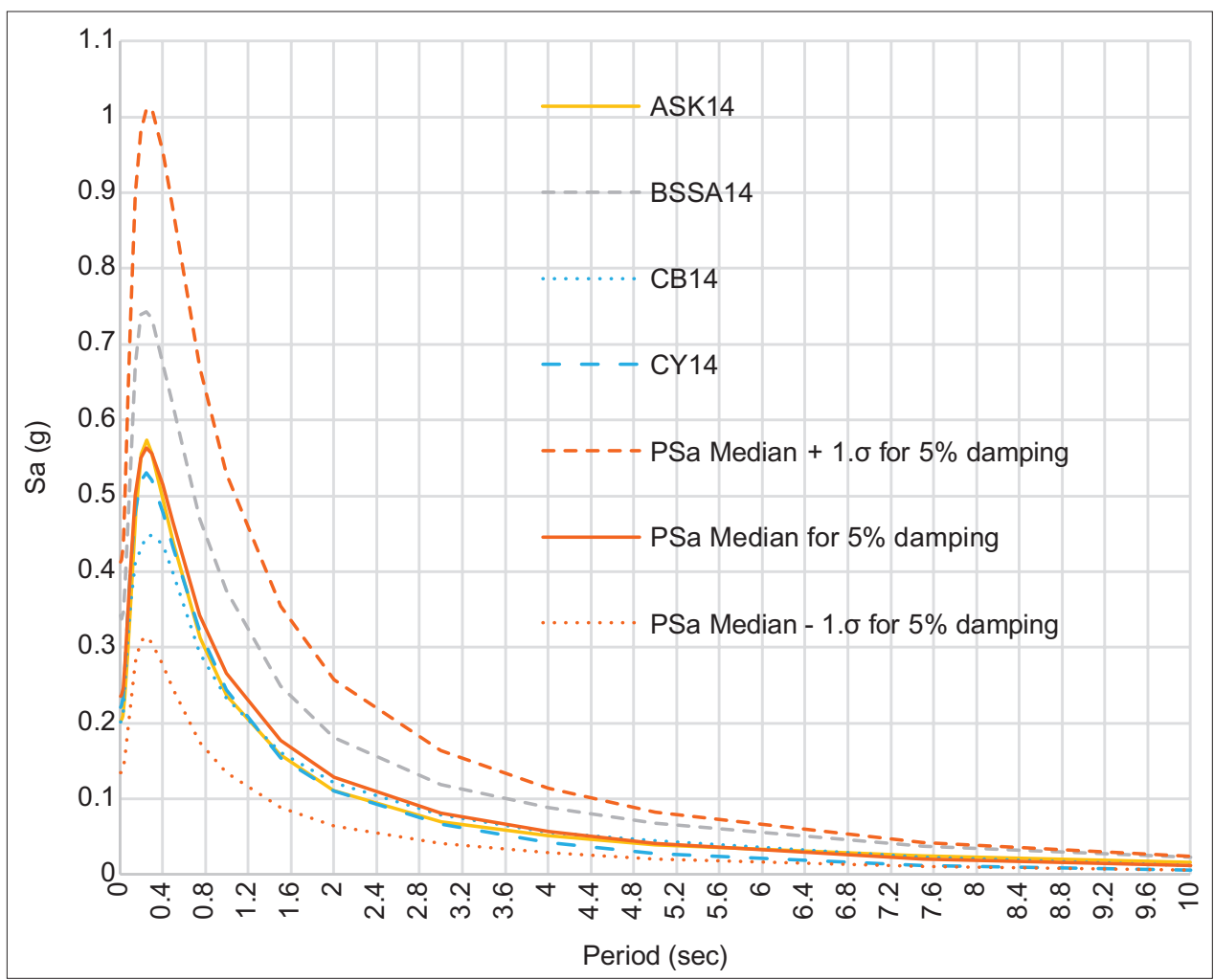

Figure 7: Proposed spectral acceleration for sta.dev. $1 \%$, damping ratio5\%, and soil site class D

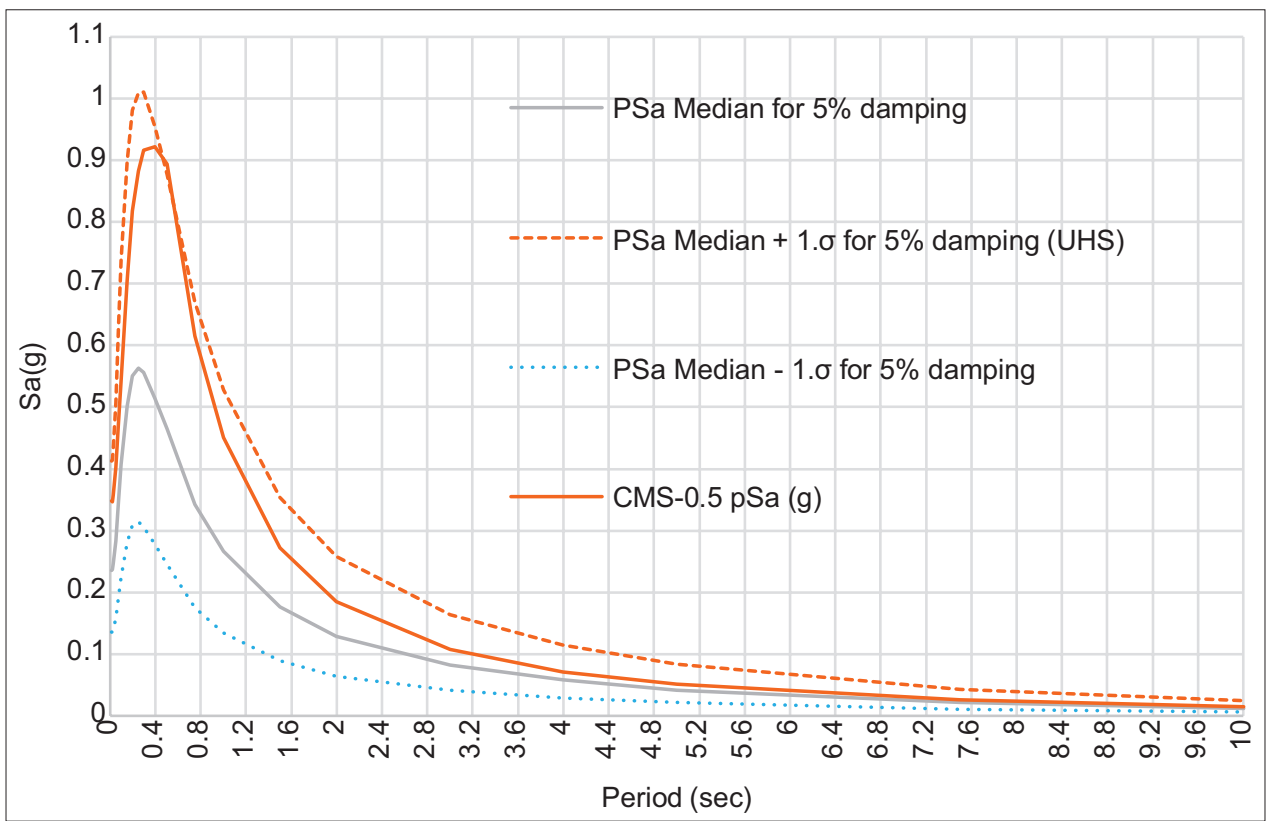

Figure 8: Proposed condition mean spectrum

non-repeating events, but they have similar properties with the selected other records [Table 2].

\section{Characteristics of Selected Ground Motion Data}

SeismoSpect (Seismosoft Ltd., V2.10) which is a software application developed by Seismosoft for earthquake tools utilized for the following objectives:
1. Used for the purpose of plotting acceleration, velocity, and displacement time histories corresponding to two orthogonal direction and vertical direction, as shown in Figure 10

2. Applied to calculate the important characteristics of the selected ground motion. Table 3 represents the important parameters to describe the amplitude and 
Table 1: Selected set of fifteen records for proposed GMSM methods from Method I, II, III, and IV

\begin{tabular}{|c|c|c|c|c|}
\hline NGA record \# & Earthquake name & Station Name & Mw & $R_{\text {rup }}(\mathrm{km})$ \\
\hline \multicolumn{5}{|l|}{ Method I } \\
\hline 6 & "Imperial Valley-02" & "El Centro Array \#9" & 6.95 & 6.09 \\
\hline 186 & "Imperial Valley-06" & "Niland Fire Station" & 6.53 & 36.92 \\
\hline 761 & "Loma Prieta" & "Fremont - Emerson Court" & 6.93 & 39.85 \\
\hline 882 & "Landers" & “North Palm Springs" & 7.28 & 26.84 \\
\hline 970 & "Northridge-01" & "El Monte - Fairview Av" & 6.69 & 44.79 \\
\hline 978 & "Northridge-01" & "Hollywood - Willoughby Ave" & 6.69 & 23.07 \\
\hline 985 & "Northridge-01" & "La - Baldwin Hills" & 6.69 & 29.88 \\
\hline 988 & "Northridge-01" & "La - Century City Cc North" & 6.69 & 23.41 \\
\hline 1000 & "Northridge-01" & "La - Pico \& Sentous" & 6.69 & 31.33 \\
\hline 1048 & "Northridge-01" & "Northridge - 17645 Saticoy St" & 6.69 & 12.09 \\
\hline 1082 & "Northridge-01" & "Sun Valley - Roscoe Blvd" & 6.69 & 10.05 \\
\hline 5969 & "Elmayorcucapah_Mexico" & "Bonds Corner" & 7.2 & 32.85 \\
\hline 6005 & "Elmayorcucapah_Mexico" & "Holtville Post Office" & 7.2 & 36.52 \\
\hline 6879 & "Darfield__New Zealand" & "Adcs" & 7 & 31.41 \\
\hline 6893 & "Darfield__New Zealand" & "Dfhs" & 7 & 11.86 \\
\hline \multicolumn{5}{|l|}{ Method II } \\
\hline 6 & "Imperial Valley-02" & "El Centro Array \#9" & 6.95 & 6.09 \\
\hline 169 & "Imperial Valley-06" & "Delta" & 6.53 & 22.03 \\
\hline 179 & "Imperial Valley-06" & "El Centro Array \#4" & 6.53 & 7.05 \\
\hline 180 & "Imperial Valley-06" & "El Centro Array \#5" & 6.53 & 3.95 \\
\hline 183 & "Imperial Valley-06" & "El Centro Array \#8" & 6.53 & 3.86 \\
\hline 185 & "Imperial Valley-06" & "Holtville Post Office" & 6.53 & 7.5 \\
\hline 1115 & "Kobe_Japan" & "Sakai" & 6.9 & 28.08 \\
\hline 4074 & "Parkfield-02_Ca" & "Parkfield - Vineyard Canyon" & 6 & 5.15 \\
\hline 5774 & "Iwate_Japan" & "Nakashinden Town" & 6.9 & 29.38 \\
\hline 5827 & "El Mayor-Cucapah_Mexico" & "Michoacan De Ocampo" & 7.2 & 15.91 \\
\hline 5969 & "El Mayor-Cucapah_Mexico" & "Bonds Corner" & 7.2 & 32.85 \\
\hline 5975 & "El Mayor-Cucapah_Mexico" & "Calexico Fire Station" & 7.2 & 20.46 \\
\hline 6005 & "El Mayor-Cucapah_Mexico" & "Holtville Post Office" & 7.2 & 36.52 \\
\hline 6969 & "Darfield_New Zealand" & "Styx Mill Transfer Station" & 7 & 20.86 \\
\hline 8606 & "El Mayor-Cucapah_Mexico" & "Westside Elementary School" & 7.2 & 11.44 \\
\hline \multicolumn{5}{|l|}{ Method III } \\
\hline 126 & "Gazli_Ussr" & "Karakyr" & 6.8 & 5.46 \\
\hline 162 & "Imperial Valley-06" & "Calexico Fire Station" & 6.53 & 10.45 \\
\hline 183 & "Imperial Valley-06" & "El Centro Array \#8" & 6.53 & 3.86 \\
\hline 549 & "Chalfant Valley-02" & "Bishop - Ladwp South St" & 6.19 & 17.17 \\
\hline 985 & "Northridge-01" & "La - Baldwin Hills" & 6.69 & 29.88 \\
\hline 1082 & "Northridge-01" & "Sun Valley - Roscoe Blvd" & 6.69 & 10.05 \\
\hline 1100 & "Kobe_Japan" & "Abeno" & 6.9 & 24.85 \\
\hline 1602 & "Duzce_Turkey" & "Bolu" & 7.14 & 12.04 \\
\hline 4207 & "Niigata_Japan" & "Nig017" & 6.63 & 12.81 \\
\hline 5781 & "Iwate_Japan" & "Misato_Miyagi Kitaura - A" & 6.9 & 38.04 \\
\hline 5829 & "Elmayor-Cucapah_Mexico" & "RIITO" & 7.2 & 13.71 \\
\hline 5837 & "Elmayor-Cucapah_Mexico" & "El Centro - Imperial \& Ross" & 7.2 & 20.08 \\
\hline 5990 & "Elmayor-Cucapah_Mexico" & "El Centro Array \#7" & 7.2 & 27.91 \\
\hline 6893 & "Darfield_New Zealand" & "Dfhs" & 7 & 11.86 \\
\hline 8124 & "Christchurchnew Zealand" & "Riccarton High School" & 6.2 & 9.44 \\
\hline \multicolumn{5}{|l|}{ Method IV } \\
\hline 126 & "Gazli_Ussr" & "Karakyr" & 6.8 & 5.46 \\
\hline 165 & "Imperial Valley-06" & "Chihuahua" & 6.53 & 7.29 \\
\hline 179 & "Imperial Valley-06" & "El Centro Array \#4" & 6.53 & 7.05 \\
\hline 183 & "Imperial Valley-06" & "El Centro Array \#8" & 6.53 & 3.86 \\
\hline 322 & "Coalinga-01" & "Cantua Creek School” & 6.36 & 24.02 \\
\hline 730 & "Spitak_Armenia" & "Gukasian" & 6.77 & 23.99 \\
\hline
\end{tabular}


Table 1: (Continued)

\begin{tabular}{|c|c|c|c|c|}
\hline NGA record \# & Earthquake name & Station Name & Mw & $R_{\text {rup }}(\mathrm{km})$ \\
\hline 949 & "Northridge-01" & "Arleta - Nordhoff Firesta" & 6.69 & 8.66 \\
\hline 1082 & "Northridge-01" & "Sun Valley Roscoe Blvd" & 6.69 & 10.05 \\
\hline 1602 & "Duzce_Turkey" & "Bolu" & 7.14 & 12.04 \\
\hline 4853 & "Chuetsu-Oki_Japan" & "Joetsu City" & 6.8 & 27.9 \\
\hline 5827 & "El Mayor-Cucapah_Mexico" & "Michoacan De Ocampo" & 7.2 & 15.91 \\
\hline 5837 & "El Mayor-Cucapah_Mexico" & "El Centro - Imperial and Ross" & 7.2 & 20.08 \\
\hline 8099 & "Christchurch_New Zealand" & "Kaiapoi North School" & 6.2 & 17.87 \\
\hline 8124 & "Christchurch_New Zealand" & "Riccarton High School" & 6.2 & 9.44 \\
\hline 8134 & "Christchurch_New Zealand" & "Styx Mill Transfer Station" & 6.2 & 11.25 \\
\hline
\end{tabular}

NGA: Next-generation attenuation relationships for the western US, Record \#: Record (Accelerogram) number in NGA-west2. Rrup: Closest distance to coseismic rupture $(\mathrm{km})$

Table 2: Selected set of ten records

\begin{tabular}{|c|c|c|c|c|c|}
\hline NGA record number & Earthquake Name & Station Name & Mw & $R_{\text {rup }}(\mathbf{k m})$ & Repeated time \\
\hline 126 & "Gazli_Ussr" & "Karakyr" & 6.8 & 5.46 & 2 \\
\hline 183 & "Imperial Valley-06" & "El Centro Array \#8" & 6.53 & 3.86 & 3 \\
\hline 5827 & "El Mayor-Cucapah_Mexico" & "Michoacan De Ocampo" & 7.2 & 15.91 & 2 \\
\hline 8124 & "Christchurch_New Zealand" & "Riccarton High School” & 6.2 & 17.87 & 2 \\
\hline 6 & "Imperial Valley-02" & "El Centro Array \#9" & 6.95 & 6.09 & 2 \\
\hline 6893 & "Darfield_New Zealand" & "Dfhs" & 7 & 11.86 & 2 \\
\hline 1602 & "Duzce_Turkey" & "Bolu" & 7.14 & 12.04 & 2 \\
\hline 1082 & "Northridge-01" & "Sun Valley - Roscoe Blvd" & 6.69 & 10.05 & 3 \\
\hline $761^{*}$ & "Loma Prieta” & "Fremont - Emerson Court" & 6.93 & 39.85 & Method I \\
\hline $730^{*}$ & "Spitak_Armenia" & "Gukasian" & 6.77 & 23.99 & Method IV \\
\hline
\end{tabular}
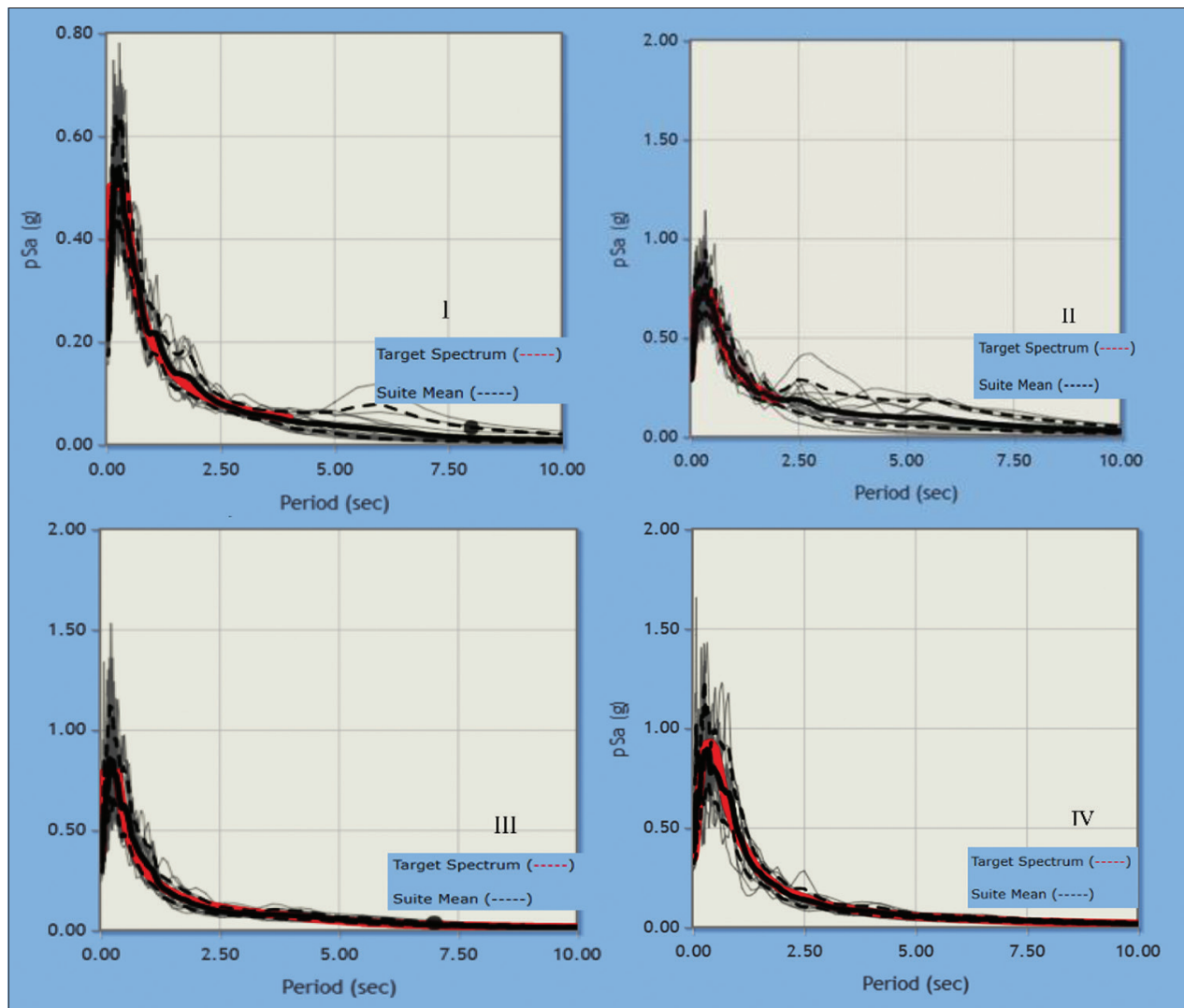

Figure 9: Response spectrum for the selected fifteen records matching the target spectrum for the selected ground motion selection and modification method in Method I, II, III, and IV 


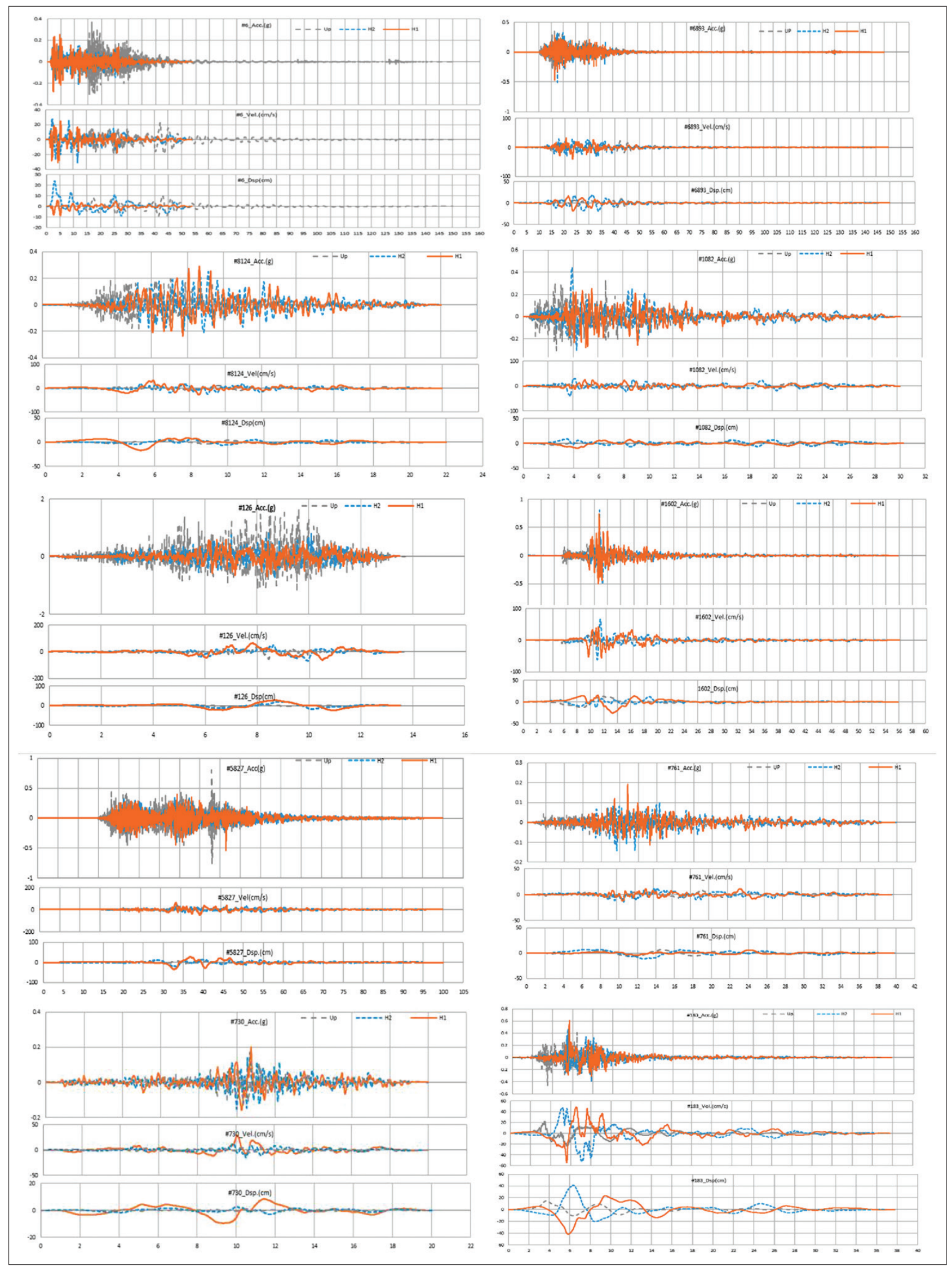

Figure 10: Acceleration, velocity, and displacement time history ground motion for ten records (\#126, \#183, \#5827, \#8124, \#6, \#6893, \#1082, \#761,1062, and \#730) considering two orthogonal direction and vertical component records 
Abduljaleel and Taha

Table 3: Ground motion parameters proposed to describe amplitude and duration

\begin{tabular}{|c|c|c|c|c|c|c|c|c|c|c|}
\hline Accelerogram & \#6 & \#126 & \#730 & \#1082 & $\# 1602$ & \#5827 & $\# 6893$ & \#8124 & \#761 & $\# 183$ \\
\hline Max acceleration (g) & 0.28 & 0.70 & 0.20 & 0.28 & 0.74 & 0.54 & 0.47 & 0.29 & 0.19 & 0.61 \\
\hline Max velocity $(\mathrm{cm} / \mathrm{sec})$ & 30.94 & 66.22 & 28.36 & 25.38 & 55.93 & 61.55 & 39.97 & 33.52 & 12.76 & 54.49 \\
\hline Max displacement $(\mathrm{cm})$ & 8.66 & 27.34 & 9.58 & 9.96 & 25.59 & 34.60 & 18.46 & 16.99 & 6.01 & 41.78 \\
\hline Vmax/Amax (sec) & 0.11 & 0.10 & 0.14 & 0.09 & 0.08 & 0.12 & 0.09 & 0.12 & 0.07 & 0.09 \\
\hline Acceleration RMS (g) & 0.04 & 0.16 & 0.03 & 0.06 & 0.07 & 0.06 & 0.03 & 0.06 & 0.02 & 0.05 \\
\hline Velocity RMS (cm/sec) & 5.28 & 19.94 & 5.44 & 6.28 & 8.35 & 9.66 & 4.74 & 8.20 & 3.01 & 10.38 \\
\hline Displacement RMS (cm) & 1.80 & 11.23 & 3.38 & 2.98 & 5.61 & 7.40 & 3.11 & 4.62 & 1.65 & 9.89 \\
\hline Arias intensity $(\mathrm{m} / \mathrm{sec})$ & 1.56 & 5.28 & 0.28 & 1.44 & 3.72 & 6.10 & 2.51 & 1.13 & 0.31 & 1.64 \\
\hline Characteristic intensity & 0.07 & 0.23 & 0.02 & 0.07 & 0.13 & 0.16 & 0.07 & 0.07 & 0.02 & 0.08 \\
\hline Specific energy density $\left(\mathrm{cm}^{2} / \mathrm{sec}\right)$ & 1498.88 & 5373.20 & 591.96 & 1192.96 & 3895.07 & 9323.51 & 3373.68 & 1479.55 & 360.73 & 4068.76 \\
\hline Cum. Abs. velocity (cm/sec) & 1331.38 & 1420.82 & 358.14 & 1008.36 & 1483.35 & 3331.99 & 1859.85 & 768.22 & 539.52 & 894.12 \\
\hline Acc spectrum intensity ( $\left.g^{*} \mathrm{sec}\right)$ & 0.28 & 0.49 & 0.14 & 0.31 & 0.64 & 0.41 & 0.32 & 0.28 & 0.13 & 0.38 \\
\hline Vel spectrum intensity $(\mathrm{cm})$ & 133.00 & 231.88 & 84.96 & 121.43 & 236.90 & 222.03 & 128.99 & 124.68 & 54.86 & 197.49 \\
\hline Housner intensity $(\mathrm{cm})$ & 129.23 & 215.69 & 76.85 & 105.51 & 214.11 & 217.88 & 120.40 & 110.56 & 48.87 & 183.89 \\
\hline Sustained max. acceleration (g) & 0.23 & 0.60 & 0.10 & 0.25 & 0.43 & 0.40 & 0.28 & 0.25 & 0.11 & 0.29 \\
\hline Sustained max velocity $(\mathrm{cm} / \mathrm{sec})$ & 28.07 & 49.27 & 12.04 & 22.88 & 41.89 & 49.08 & 28.11 & 26.44 & 10.55 & 46.06 \\
\hline Effective Design acceleration (g) & 0.28 & 0.54 & 0.19 & 0.28 & 0.63 & 0.51 & 0.45 & 0.30 & 0.19 & 0.56 \\
\hline A95 parameter $(\mathrm{g})$ & 0.28 & 0.69 & 0.20 & 0.27 & 0.73 & 0.52 & 0.47 & 0.29 & 0.19 & 0.61 \\
\hline Predominant period (sec) & 0.50 & 0.10 & 0.00 & 0.20 & 0.35 & 0.30 & 0.20 & 0.60 & 0.00 & 0.08 \\
\hline Significant duration (sec) & 24.19 & 6.38 & 10.54 & 12.22 & 8.55 & 32.67 & 21.26 & 9.49 & 17.24 & 6.82 \\
\hline Max incremental velocity $(\mathrm{cm} / \mathrm{sec})$ & 53.25 & 68.93 & 36.27 & 39.17 & 61.89 & 86.38 & 46.64 & 36.23 & 18.44 & 65.27 \\
\hline Damage Index $\left((\mathrm{g})^{\wedge} \mathrm{c}\right)$ & 2.33 & 22.25 & 0.26 & 2.25 & 4.55 & 13.39 & 5.09 & 1.52 & 0.43 & 3.25 \\
\hline Number of effective cycles & 4.39 & 7.32 & 1.74 & 4.32 & 1.48 & 10.27 & 4.56 & 3.95 & 5.45 & 2.02 \\
\hline IP Index & 43.01 & 20.82 & 12.67 & 39.52 & 26.60 & 54.03 & 47.71 & 22.96 & 42.70 & 16.42 \\
\hline Sa,avg (g) & 0.32 & 0.54 & 0.19 & 0.27 & 0.54 & 0.53 & 0.31 & 0.27 & 0.13 & 0.46 \\
\hline
\end{tabular}

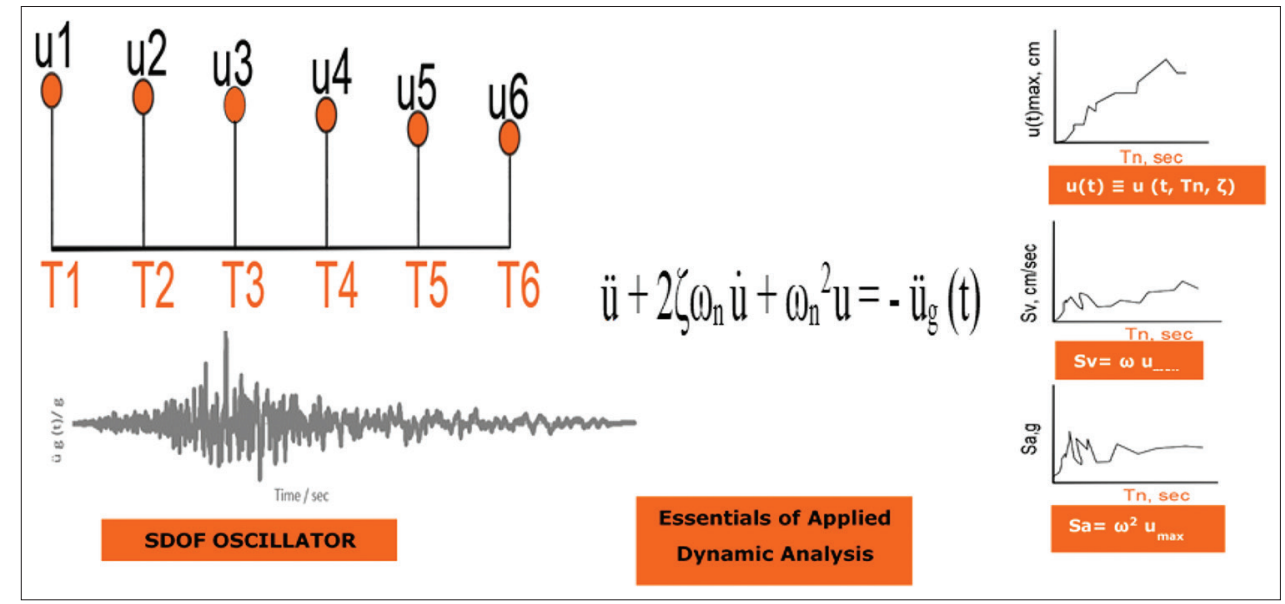

Figure 11: Ideal response spectra obtained from the time history

duration, the detail definition of parameters explained by Kramer in his book (Kramer, 1996)

3. Applied to calculate RS to describe the frequency content. $\mathrm{RS}$ can be determined by the plot of maximum response linear single degree of freedom oscillator (SDOF) for a given component of earthquake ground motion depends only on the natural frequency and damping.

Figure 11 represents the brief process to obtain the spectral acceleration from the ground motion (time history), which spectral acceleration curve can be represented by the max response of the SDOF induced by ground motion $\ddot{u}_{g}(t)$. Equation $\ddot{\mathrm{u}}+2 \zeta \omega_{n} \dot{\mathrm{u}}+\omega_{n}^{2} \mathrm{u}=-\ddot{\mathrm{u}}_{\mathrm{g}}(\mathrm{t})$ governs the motion of linear SDOF system, where the max deformation response of the system $\mathrm{u}(\mathrm{t}) \equiv \mathrm{u}\left(\mathrm{t}, \mathrm{T}_{\mathrm{n}}, \zeta\right)$ depends on the natural frequency $\omega_{n}$ or natural period $T_{n}$, and damping ratio $\zeta$. The peak relative displacement $\mathrm{u}(\mathrm{t})$ could be calculated by numerical methods and converted into pseudospectral velocity by multiplying the natural frequency and represented with pseudo-spectral acceleration by 


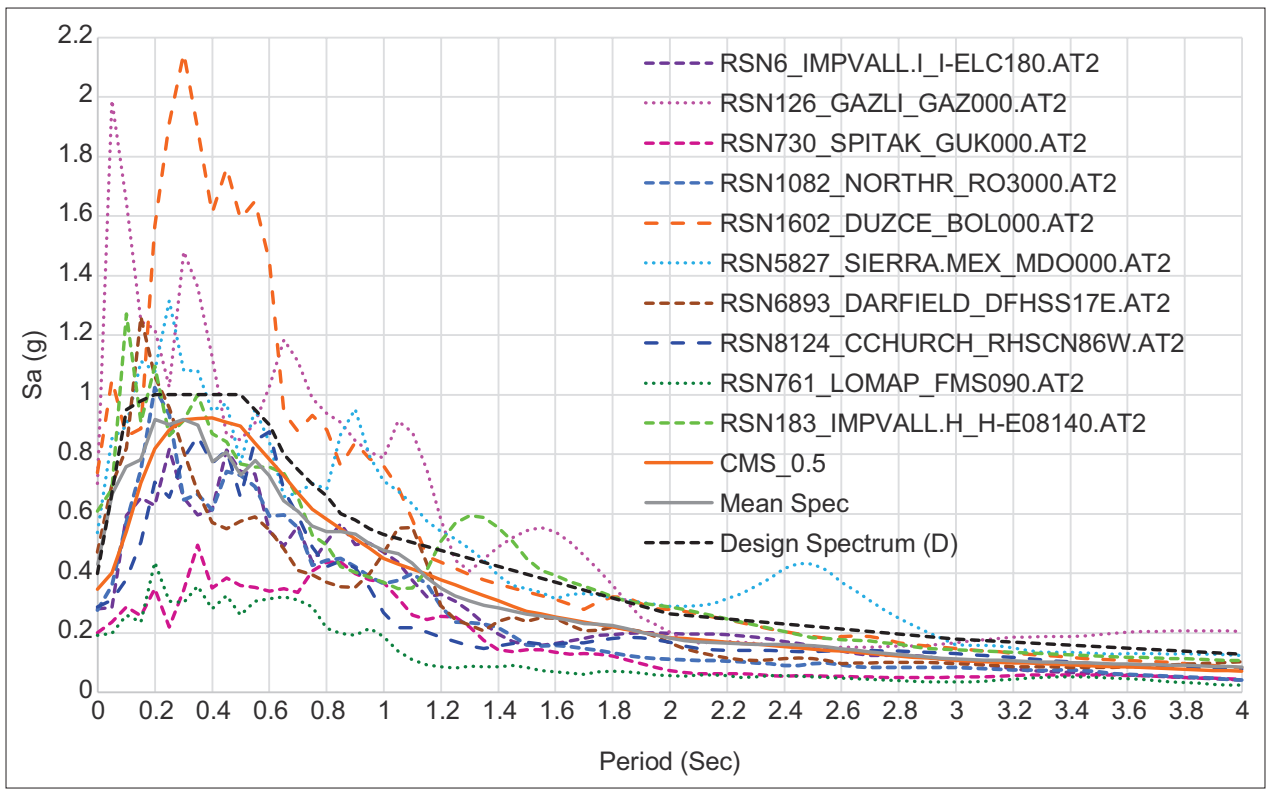

Figure 12: Comparison of spectral record ground motion and target spectrum

multiplying the squared natural frequency. Figure 12 determines the spectra comparison of the ground motion records and their mean spectra with (CMS/0.5) target spectrum.

\section{CONCLUSION}

Input ground motions are a fundamental component in the studying of seismic risk studies as they remarkably affect the output results. Therefore, this study concentrating on the selection of the ground motions compatible with the characteristics of Erbil city. Four sets of GMSM methods with fifteen records derived from online database PEERNGA and scaled to match the seismic characteristic of Erbil city and the target spectra defined by the draft of Iraqi Seismic Code 2016; updated PSHA for Iraq 2018; ASCE code/PSHA defined Arabian plate; and proposed CMS. Based on the proposed methodology appropriate ten records selected and Seismosoft used for plotting acceleration, velocity, and displacement time histories corresponding to two orthogonal direction and vertical direction, furthermore, to assess the important parameters to characterize the amplitude, frequency content, and duration of selected ground motion.

\section{ACKNOWLEDGMENT}

Thanks to Dr. Abdulhameed Abdullah Yaseen from the University of Duhok, for their writing insightful comments. I am also thankful to Dr. Kevin Franke from Brigham Young University, for providing online courses about Geotechnical Analysis of Earthquake.

\section{REFERENCES}

Abdulnaby, W., H. Mahdi, N. M. Numan and H. Al-Shukri. 2014a. Seismotectonics of the Bitlis-Zagros fold and thrust belt in Northern Iraq and surrounding regions from moment tensor analysis. Pure Appl. Geophys. 171: 1237-1250.

Abdulnaby, W., H. Mahdi, H. Al-Shukri and N. M. Numan. 2014b. Stress patterns in Northern Iraq and surrounding regions from formal stress inversion of earthquake focal mechanism solutions. Pure Appl. Geophys. 171: 2137-2153.

Abrahamson, N. A. 1992. Non-stationary spectral matching. Seismol. Res. Lett. 63: 30.

Abrahamson, N. A., W. J. Silva and R. Kamai. 2014. Summary of the ASK14 ground motion relation for active crustal regions. Earthq. Spectra. 30: 1025-1055.

Al-Shijbi, Y., I. El-Hussain, A. Deif, A. Al-Kalbani and A. M. Mohamed. 2018. Probabilistic seismic hazard assessment for the Arabian peninsula. Pure Appl. Geophys. 161: 1-28.

Alsinawi, S. A. 2006. Seismicity. In: Jassim, S. Z. and J. C. Goff, editors. Geology of Iraq(pp.84-90).

Ancheta, T. D., R. B. Darragh, J. P. Stewart, E. Seyhan, W. J. Silva, B. S. J. Chiou, K. E. Wooddell, R. W. Graves, A. R. Kottke and D. M. Boore. 2014. NGA-West2 database. Earthq. Spectra. 30: 989-1005.

ASCE/ASE07-10. 2013. Minimum Design Loads for Buildings and Other Structures. $7^{\text {th }}$ ed. American Society of Civil Engineers, Reston, VA.

ASCE/SEI 7-10. 2010. Minimum Design Loads for Buildings and other Structures. American Society of Civil Engineers, Reston, VA.

ATC. 2011. Seismic Performance Assessment of Buildings. Vol. 1. ATC, United States. p94065.

Baker, J. W. 2011. Conditional mean spectrum: Tool for groundmotion selection. J. Struct. Eng. 137: 322-331.

Baker, J. W. 2015. Ground Motion Selection for Performancebased Engineering, and the Conditional Mean Spectrum as a Selection Tool. Proceedings of the Tenth Pacific Conference on Earthquake Engineering Building an Earthquake-resilient Pacific, Sydney, Australia. 
Baker, J. W. and N. Jayaram. 2008. Correlation of spectral acceleration values from NGA ground motion models. Earthq. Spectra. 24: 299-317.

Bommer, J. J. and A. B. Acevedo. 2004. The use of real earthquake accelerograms as input to dynamic analysis. J. Earthq. Eng. 8: 43-91.

Boore, D. M., J. P. Stewart, E. Seyhan, G. M. and Atkinson. 2014. NGA-West2 equations for predicting PGA, PGV, and 5\% damped PSA for shallow crustal earthquakes. Earthq. Spectra. 30: 1057-1085.

Campbell, K. W. and Y. Bozorgnia. 2014. NGA-West2 ground motion model for the average horizontal components of PGA, PGV, and $5 \%$ damped linear acceleration response spectra. Earthq. Spectra. 30: 1087-1115.

Chiou, B. S. J. and R. R. Youngs. 2014. Update of the Chiou and Youngs NGA model for the average horizontal component of peak ground motion and response spectra. Earthq. Spectra. 30: 1117-1153.

Das, A., V. Patel and A. Ghosh. 2018. Ground motion selection considering seismicity of the area and response of the structure. Int. J. Eng. Res. Technol. 7: 21.

Draft/Code-16. 2016. Draft of Iraqi Seismic Code. Submitted to Central Organization for Standardization and Quality Control COSQC, Iraq, Baghdad.

El-Hussain, I., Y. Al-Shijbi, A. Deif, A. M. E. Mohamed and M. Ezzelarab. 2018. Developing a seismic source model for the Arabian plate. Arab. J. Geosci. 11: 435.

Fouad, S. F. 2015. Tectonic map of Iraq, scale 1: 1000 000, 2012. Iraqi Bull. Geol. Min. 11: 1-7.

Fouad, S. F. and V. K. Sissakian. 2015. Geological map of Iraq, Scale 1: 1000 000, 2012. Iraqi Bull. Geol. Min. 11: 9-16.

Galin, S. 2012. Selection and Scaling of Seismic Excitations for Timehistory Analysis of Reinforced Concrete Frame Buildings (PhD Thesis). Université d' Ottawa/University of Ottawa, Ottawa.

Ghalib, H. A. A. and G. I. Aleqabi. 2016. Seismicity, velocity structure and tectonics of the Arabian plate. J. Zankoy. Sulaimani. 18-1: 481-497.

Goulet, C. A., J. Watson-Lamprey, J. Baker, C. Haselton and N. Luco. 2008. Assessment of ground motion selection and modification (GMSM) methods for non-linear dynamic analyses of structures. In: Geotechnical Earthquake Engineering and Soil Dynamics IV. American Society of Civil Engineers, United States. p1-10.

Hancock, J., J. Watson-Lamprey, N. A. Abrahamson, J. J. Bommer, A. Markatis, E. McCOY and R. Mendis. 2006. An improved method of matching response spectra of recorded earthquake ground motion using wavelets. J. Earthq. Eng. 10: 67-89.
Haselton, C. B., J. W. Baker, Y. Bozorgnia, C. A. Goulet, E. Kalkan, N. Luco, T. Shantz, N. Shome, J. P. Stewart and P. Tothong. 2009. Evaluation of Ground Motion Selection and Modification Methods: Predicting Median Interstory Drift Response of Buildings. PEER Ground Motion Selection and Modification Working Group. National Technical Reports Library, United States. p1.

Hosseini, R., G. R. Lashkaripour, N. H. Moghaddas and M. Ghafoori. 2014a. Proposed seismotectonic provinces for Kurdistan regionNorth-Eastern Iraq. Int. J. Curr. Life Sci. 4:9060-9066.

Hosseini, R., G. R. Lashkaripour, N. H. Moghaddas and M. Ghafoori. 2014b. Probabilistic Seismic Hazard for Kurdistan Region-NE Iraq. $2^{\text {nd }}$ International Congress of Structure, Architecture and Urban Development, Tabriz Iran.

Kramer, S. L. 1996. Geotechnical earthquake engineering. In: Prentice-Hall International Series in Civil Engineering and Engineering Mechanics. Prentice-Hall, United States.

Mohammed, Q. S. A. and M. A. Abdulrassol. 2017. Database of dynamic soil properties for most Iraq soils. Am. Sci. Res. J. Eng Technol. Sci. 37: 230-254.

Onur, T., R. Gok, W. Abdulnaby, A. M. Shakir, H. Mahdi, N. Numan, H. Al-Shukri, H. K. Chlaib, T. H. Ameen and N. A. Abd. 2016. Probabilistic Seismic Hazard Assessment for Iraq. Lawrence Livermore National Lab.(LLNL), Livermore, CA, United States.

PEER. 2018. Pacific Earthquake Engineering Research Center, NGA Database. Available from: https://www.ngawest2. berkeley.edu/spectras/new?sourceDb_flag=1. [Last accessed on 2018 Oct 12].

Reyes, J. C. and E. Kalkan. 2011. Required Number of Records for ASCE/SEI 7 Ground-motion Scaling Procedure. US Department of the Interior, Geological Survey, India.

Said, A. I. and M. S. Farman. 2018a. Re-evaluations of seismic hazard of Iraq. Arab. J. Geosci. 11: 279.

Said, A. I. and M. S. Farman. 2018b. Updated probabilistic seismic hazard assessment for Iraq/2018. Civ. Eng. J. 4: 1610-1628.

Seismosoft Ltd., V2.10. 2018. Available from: http://www. seismosoftcomAcad.License.SeismosoftOGMeta. [Last accessed on 2018 Nov 24].

Yaseen, A., D. Begg and N. Nanos. 2015. Seismic fragility assessment of low-rise unreinforced masonry buildings in the Kurdistan region of Iraq. Int. J. Struct. Anal. Des. 2: 1-9.

Yaseen, A. A., D. Begg and N. Nanos. 2014. Time History Analysis of Existing Buildings in the Kurdistan Region of Iraq. Presented at the $1^{\text {st }}$ International Engineering Conference on Developments in Civil and Computer Engineering Applications (IEC2014, Erbil, Kurdistan Regional Government (KRG) of Iraq, Erbil. 